Available online at http://journal.stkip-andi-matappa.ac.id/index.php/histogram/index

Histogram: Jurnal Pendidikan Matematika 4(2)., 2020, 439 - 450

\title{
LINTASAN BELAJAR GEOMETRI TRANSFORMASI DENGAN MENGGUNAKAN KONTEKS KAIN BUNA
}

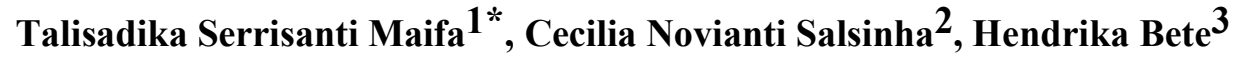 \\ 1,2,3 Universitas Timor \\ * Corresponding Author. Email: talisadikamaifa@unimor.ac.id \\ Received: 21 Juli 2020; Revised: 15 September 2020 ; Accepted: 30 September 2020
}

\begin{abstract}
ABSTRAK
Penelitian bertujuan untuk mendesain sebuah lintasan belajar pada materi Geometri Transfromasi dengan menggunakan konteks Kain Tenun Buna berdasarkan pendekatan Pendidikan Matematika Realistik Indonesia (PMRI). Penelitian ini adalah Design Research yang terdiri dari 3 tahap yaitu Preliminary design, experimental design, dan analysis retrospective. Hasil dari penelitian adalah sebuah lintasan belajar untuk materi Geometri Transformasi, khsusunya materi Refleksi. Lintasan belajar didesain dengan menggunakan 4 aktivitas yaitu: Menggambar Pola Kain tenun, Menciplak Pola Kain tenun, Menemukan Bayangan, dan Menemukan Rumus Refleksi. Hasil penelitian yang diperoleh adalah lintasan belajar ini mampu mendukung siswa untuk memahami konsep Geometri Transformasi.
\end{abstract}

Kata Kunci:, Lintasan Belajar, Refleksi, Geometri

ABSTRACT

This study is aimed to design a mathematics learning trajectory in geometry transformation using Buna Woven Fabric as a context in the learning process with the Indonesian Realistic Mathematics Education (RME) approach. This study is a a design research that contains three stages, preliminary design, teaching experiment, and retrospective analysis. The result of this research is the learning trajectory design of geometry transformation especially Reflection using Buna woven fabric. The design consists of four activities, namely, drawing woven fabric patterns, copying woven fabric patterns, finding the image of transformation, and finding the formula of reflection. The results indicated the learning trajectory can stimulate students to understand the concept of geometry transformation.

Keywords: Learning Trajectory, Reflection, Geometry

How to Cite: Maifa, T, S., Salsinha, C, N., \& Bete, H. (2020). Lintasan Belajar Geometri Transformasi Dengan Menggunakan Konteks Kain Buna. Histogram: Jurnal Pendidikan Matematika, 4(2), 439 - 450, doi: http://dx.doi.org/10.31100/histogram.v4i2.696 Permalink/DOI:

http://dx.doi.org/10.31100/histogram.v4i2.696

\section{PENDAHULUAN}

Geometri Transformasi (Selanjutnya GT) merupakan salah satu materi geometri yang dipelajari dari tingkat sekolah hingga perkuliahan. Pada tingkat sekolah, materi GT yang dipelajari adalah translasi, refleksi, rotasi, dan dilatasi. Sedangkan, di tingkat perkuliahan mahasiswa dikenalkan pada GT sebagai suatu fungsi injektif.

Dalam perkembangannya, GT masih merupakan materi sulit yang kurang dikuasai oleh siswa (Basuki, 2012). Sudarja dkk (2018) menemukan bahwa dalam mempelajarai GT siswa mengalami kesulitan dalam mengaitkan gambar yang mereka dapati ke dalam suatu ide matematika dan juga sebaliknya ketika siswa menjelaskan sebuah ide matematika dalam bentuk tulisan ataupun gambar. Tidak jauh berbeda, ditingkat perkuliahan pun 


\section{Histogram: Jurnal Pendidikan Matematika, 4 (2), 2020 - 440 \\ Talisadika Serrisanti Maifa ${ }^{1^{*}}$, Cecilia Novianti Salsinha ${ }^{2}$ Hendrika Bete ${ }^{3}$}

mahasiswa masih melakukan kesalahan-kesalahan dalam memahami konsep GT (Maifa, 2019a).

Cara pemahaman konsep yang baik bagi siswa adalah melalui pembelajaran yang dekat dengan kehidupan sehari-harinya. Pendekatan yang dapat digunakan untuk memberi suatu pengalaman belajar bagi siswa adalah Pendekatan Matematika Realistik Indonesia (PMRI). Susanti \& Suparman (2018) dalam penelitianya menemukan bahwa pendekatan ini jauh lebih baik hasilnya daripada pembelajaran yang menerapkan pendekatan lain yang biasa digunakan. Pendekatan ini menggunakan sebuah konteks sebagai titik awal pembelajaran (Zulkardi \& Ilma, 2006) dimana sebuah konteks dapat berupa berbagai hal dalam kehidupan sehari-hari siswa, salah satunya adalah konteks budaya. Novrika dkk. (2016) mengembangkan sebuah desain pembelajaran dengan pendekatan PMRI menggunakan konteks budaya lokal berupa kain batik. Hasilnya adalah siswa mampu memahami konsep materi GT pada materi refleksi dengan baik.

Salah satu konteks kehidupan berbudaya yang dapat dimanfaatkan dalam pembelajaran dengan PMRI adalah motif kain tenun. Salah satu motif kain yang dimiliki oleh masyarakat Timor Tengah Utara di Propinsi Nusa Tenggara Timur adalah motif kain tenun Buna. Motif ini berwarna dasar hitam dan putih dengan kombinasi warna merah hati, biru, kuning, coklat, dan orange. Awalnya kain ini dikenakan oleh kaum bangsawan tetapi saat ini masyarakat biasa pun dapat mengenakan motif ini dalam banyak kegiatan seperti acara adat, pemerintahan, pernikahan dan lainnya. Ndapa Deda \& Disnawati (2017) dalam penelitiannya juga menyimpulkan bahwa motif ini dapat dijadikan sebagai materi dalam pembelajaran geometri karena adanya beberapa pola seperti garis, segi empat, dan refleksi, sehingga motif ini tepat digunakan sebagai konteks dalam pembelajaran geometri transformasi.

PMRI dengan menggunakan konteks budaya berupa kain motif kain tenun memungkinkan didesainnya sebuah lintasan belajar untuk materi GT. Penelitian ini menghasilkan sebuah desain lintasan belajar materi GT menggunakan motif kain Buna.

\section{METODE PENELITIAN}

\section{A. Jenis Penelitian}

Penelitian merupakan penelitian dengan pendekatan kualitatif yaitu design research. Design research dipilih dalam penelitian ini karena metode ini bertujuan untuk mengembangkan sebuah desain lintasan belajar yang dihasilkan oleh guru dan juga peneliti dalam rangka meningkatkan kualitas dalam kegiatan pembelajaran (Gravemeijer 
Histogram: Jurnal Pendidikan Matematika, 4 (2), 2020 - 441

Talisadika Serrisanti Maifa ${ }^{{ }^{*}}$, Cecilia Novianti Salsinha ${ }^{2}$ Hendrika Bete ${ }^{3}$

\& Eerde, 2009). Menurut Gravemeijer \& Cobb (2006) design research terdiri dari tiga tahap:

1. Preliminary Design.

Tujuan utama pada tahap ini adalah untuk mendesain sebuah Hypotetical Learning Trajectory (HLT). Pada penelitian ini, HLT didesain dengan mengkaji literatur GT, motif kain tenun Buna, dan PMRI. HLT terdiri dari beberapa hal yaitu tujuan dari pembelajaran, aktivitas dalam pembelajaran dan konjektur berpikir siswa.

2. Experimental Design

Tahap ini terdiri dari 2 kegiatan:

a. Pilot Experiment

Tahap ini HLT diujicobakan kepada 4 siswa dengan tujuan untuk meningkatkan kualitas HLT yang pada akhirnya diperoleh sebuah HLT yang jauh lebih baik untuk diimplementasikan di tahap berikutnya . Hasil dari tahap ini adalah sebuah HLT yang telah direvisi.

b. Teaching Experiment

HLT yang telah direvisi diterapkan dengan tujuan untuk melihat bagaimana HLT mendukung siswa untuk memahami konsep GT.

3. Retrospective Analysis

Secara umum tahapan ini merupakan kegiatan menganalisis setiap tahapan yang telah dilakukan. Setelah tahap pilot experiment maka semua data yang diperoleh dianalisis dan hasilnya digunakan untuk memperbaiki HLT. Terdapat beberapa hal yang dianalisis yaitu hal atau kejadian yang mendukung HLT dan juga hal-hal yang tidak sesuai dengan konjektur berpikir dari siswa yang telah didesain. HLT yang telah diperbaiki kemudian diimplementasikan ditahap teaching experiment, kemudian setelah itu dilakukan lagi tahap analisis. Hasil akhir dari analisis inilah akan didapatkan sebuah desain lintasan belajar GT.

\section{B. Subjek Penelitian}

Empat siswa terlibat pada tahap pilot experiment dan dua puluh siswa untuk tahap teaching experiment.

\section{Tekhnik Analisis Data}

HLT merupakan panduan utama dalam melakukan kegiatan analisis. Aktivitas siswa selama teaching experiment kemudian dibandingkan dengan HLT. Data yang 


\section{Histogram: Jurnal Pendidikan Matematika, 4 (2), 2020 - 442 \\ Talisadika Serrisanti Maifa ${ }^{1^{*}}$, Cecilia Novianti Salsinha ${ }^{2}$ Hendrika Bete ${ }^{3}$}

dikumpulkan selama pelaksanaan penelitian yaitu hasil pekerjaan siswa, catatan selama observasi, video, dan foto dianalisis untuk menjawab masalah dalam penelitian ini. Hal ini bertujuan untuk menguji kevalidan data. Untuk Reliabilitas data secara internal maka selain aktivitas di kelas maka dilakukan juga diskusi mengenai hal-hal penting selama pelaksanaan penelitian bersama guru untuk menghindari terjadinya subjektifitas selama penelitian.

\section{HASIL DAN PEMBAHASAN}

\section{A. Hasil Penelitian}

Hasil penelitian adalah sebuah lintasan belajar GT dengan konteks Motif Kain Buna untuk materi Refleksi. Dimana dengan lintasan belajar ini siswa memahami konsep Refleksi dan bagaimana menemukan rumus Refleksi. Lintasan belajar ini terdiri dari empat aktivitas yaitu: Menggambar Pola Kain Tenun, Menciplak Pola Kain Tenun, Menemukan Bayangan, dan Menemukan Rumus Refleksi. Aktivitas pertama hingga ketiga merupakan aktivitas untuk pemahaman konsep refleksi, sedangkan aktiftas terakhir merupakan aktiftas untuk menemukan kembali rumus refleksi terhadap sumbu $y$ dan sumbu $x$.

\section{Menggambar Pola Kain Tenun}

Motif kain ini dipilih sebagai konteks dalam pembelajaran karena Eko (2017) menyimpulkan bahwa Motif kain ini mengandung konsep GT dan motif yang dominan pada kain tenun Buna adalah belah ketupat. Pada aktivitas pertama ini siswa diberikan motif kain Buna dan kemudian diminta untuk mengeksplorasi unsur matematika apa saja yang ada pada motif kain

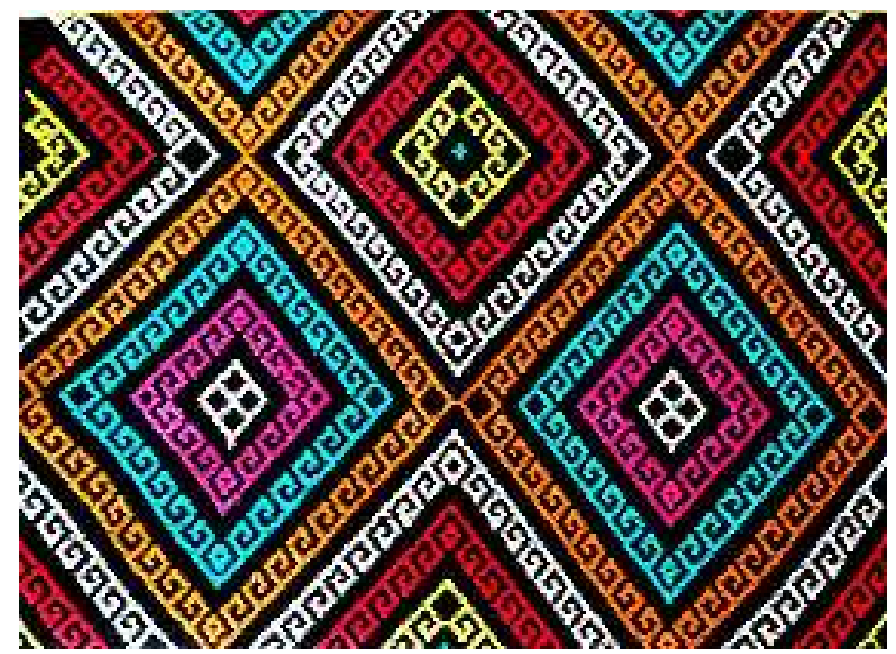

Gambar 1. Motif Kain Tenun Buna 
Histogram: Jurnal Pendidikan Matematika, 4 (2), 2020 - 443

Talisadika Serrisanti Maifa ${ }^{{ }^{*}}$, Cecilia Novianti Salsinha ${ }^{2}$ Hendrika Bete $^{3}$

Adapun yang ditemukan siswa pada motif kain Buna ini adalah garis dan bentuk segi empat yaitu belah ketupat. Setelah itu, siswa diminta untuk menggambarkan pola kain tenun dengan cara mereka sendiri dan dalam waktu yang singkat. Aktivitas pertama ini bertujuan agar siswa dapat menemukan kegiatan menciplak sebagai cara yang cepat untuk menggambar pola dari kain tenun. Setelah menggambarkan pola kain tenun, siswa diarahkan untuk mengoreksi pekerjaan mereka sendiri, dengan memperhatikan apakah bentuk yang sudah dikerjakan merupakan belah ketupat. Siswa kemudian menemukan bahwa bentuk pola yang dihasilkan mereka yang ditunjukkan pada gambar 2 bukanlah sebuah segi empat, karena ketika siswa mengukur sisi-sisinya ternyata tidak sama panjang.

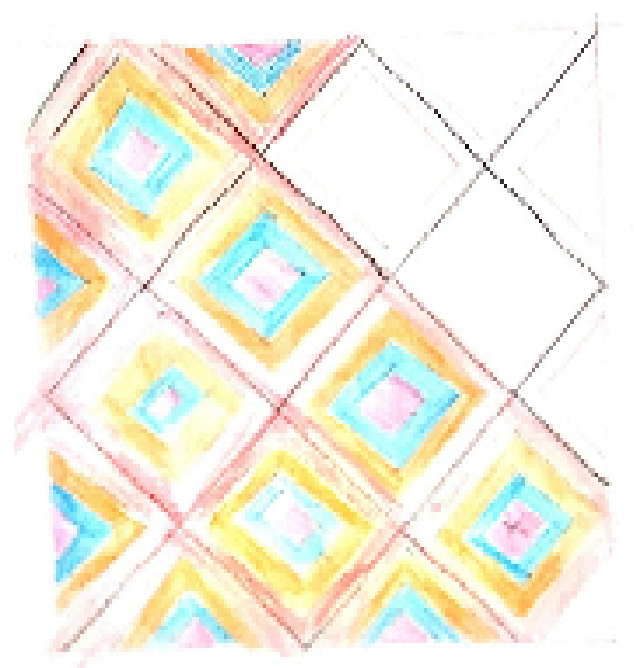

Gambar 2. Pola Kain Tenun Buatan Siswa

Siswa kemudian diarahkan untuk mengamati adakah bentuk yang simetris pada pola kain tenun tersebut. Dengan pengetahuan awal mereka bahwa bentuk tersebut adalah belah ketupat, siswa dapat menemukan adanya bentuk yang simetris pada sisi-sisinya. Guven (2012) menyebutkan bahwa dengan mempelajari transformasi, siswa dapat diarahkan untuk melakukan eksplorasi konsep simetri.

2. Menciplak Pola Kain Tenun

Selanjutnya, Siswa diberikan alat dan bahan berupa kertas, pena, dan kertas karbon. Dengan mengarahkan cara menggunakan kertas karbon, siswa kemudian mencoba dengan cara mereka sendiri bagaimana mendapatkan pola kain tenun, dengan pemahaman bahwa bentuk dari belah ketupat simetris dan memiliki panjang sisi yang sama. Maka berikut adalah tahapan yang dialami oleh siswa. 
Histogram: Jurnal Pendidikan Matematika, 4 (2), 2020 - 444

Talisadika Serrisanti Maifa ${ }^{{ }^{*}}$, Cecilia Novianti Salsinha ${ }^{2}$ Hendrika Bete ${ }^{3}$

a. Siswa menggambarkan dua sisi dari belah ketupat yang merupakan pola dari kain tenun

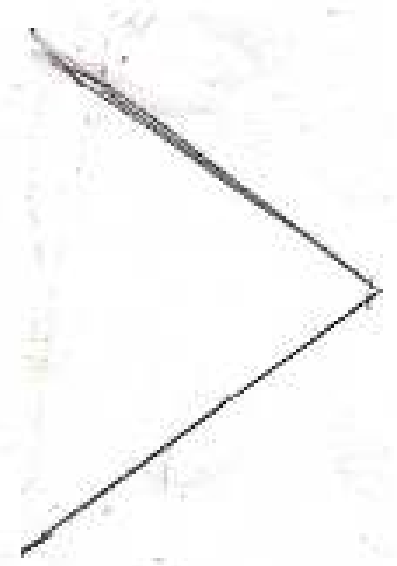

Gambar 3. Pola dua sisi belah ketupat buatan siswa

b. Siswa melipat kertas tepat di akhir 2 sisi tersebut seperti yang ditunjukkan oleh gambar. Garis merah menunjukkan lipatan yang dibuat siswa. Kemudian dengan menggunakan kertas karbon mendapatkan 2 sisi lainnya.

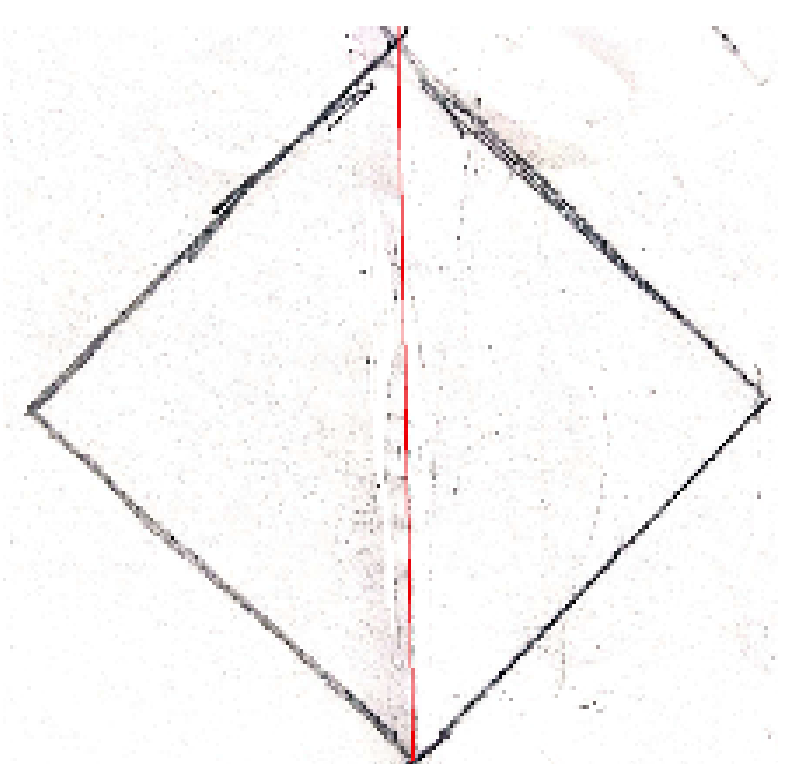

Gambar 4. Pola belah ketupat buatan siswa

Aktivitas kemudian dilanjutkan dengan siswa menggambarkan pola motif kain tenun Buna yang terdiri dari beberapa belah ketupat pada kertas berpetak. Tahap ini siswa menggunakan 2 cara, (1) siswa menggunakan kertas karbon dan kertas berpetak, dimana siswa menggambarkan pola 4 buah belah ketupat seperti pada motif kain tenun Buna pada 
Histogram: Jurnal Pendidikan Matematika, 4 (2), 2020 - 445

Talisadika Serrisanti Maifa ${ }^{{ }^{*}}$, Cecilia Novianti Salsinha ${ }^{2}$ Hendrika Bete ${ }^{3}$

gambar 1 dengan menggunakan kertas karbon, (2) siswa menggambarkan pola 4 buah belah ketupat dengan cara menghitung jarak dari tiap kotak pada kertas berpetak, seperti yang ditunjukkan aktivitas siswa pada gambar 5. Berikut percakapa siswa yang menggambar pola dengan cara menghitung kotak pada kertas berpetak dengan peneliti.

Peneliti : "Bagaimana kamu tahu bahwa jaraknya harus sama?"

Siswa: "Hitung, kan dari sini, ini ke sini, kalau ke sini, 1,2,3,4, berhentinya di sini, berarti ke bawahnya harus sama, 1,2,3,4 (Menghitung jarak dengan menghitung kotak pada kertas berpetak)

Peneliti : "Kenapa harus sama?"

Siswa : "Karena harus sama"

Dari percakapan di atas terlihat bahwa siswa memahami adanya sesuatu yang menjadi patokan atau acuan untuk menggambar sehingga bentuk dari suatu pola menjadi simetris. Dengan pemahaman ini siswa dengan mudah diarahkan untuk memahami tentang sumbu simetri dan kemudian sumbu refleksi, dimana jarak titik sebelum dan sesudah direfleksikan adalah sama. Namun ketika ditanyakan lagi mengapa jaraknya harus sama, siswa hanya menjawab dengan alasan "karena harus sama".

Dapat disimpulkan bahwa siswa memiliki suatu pemahaman konsep berupa menggambar dan mengidentifikasi, namun kesulitan dalam menjelaskan. Ini merujuk pada Jumrah (2017) yang menyebutkan bahwa pemahaman konsep geometri antara lain adalah kemampuan untuk menggambarkan sesuatu, menjelaskan, menggolongkan dan mengidentifikasi, kemudian menunjukkan konsep yang telah diterimanya dengan caranya sendiri.

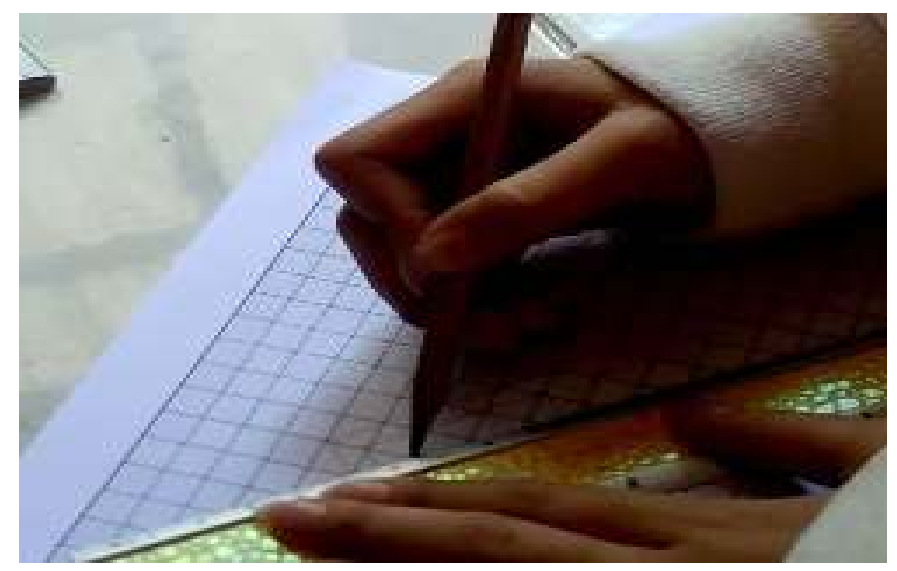

Gambar 5. Siswa menggambar pola dengan menghitung kotak. 


\section{Histogram: Jurnal Pendidikan Matematika, 4 (2), 2020 - 446 \\ Talisadika Serrisanti Maifa ${ }^{1^{*}}$, Cecilia Novianti Salsinha ${ }^{2}$ Hendrika Bete ${ }^{3}$}

Dengan menggunakan 2 cara diatas siswa pada akhirnya mampu menggambarkan pola kain tenun Buna. Selanjutnya siswa diarahkan untuk meletakkan sumbu $x$ dan sumbu $y$ pada gambar pola yang telah mereka buat sesuai dengan posisi lipatan mereka ketika menggambarkan pola dengan kertas karbon. Siswa yang tetap menggunakan kertas karbon dengan mudah diarahkan untuk meletakkan sumbu $x$ dan sumbu $y$, sedangkan siswa yang menggambar pola dengan pemahaman menghitung kotak diminta untuk memperhatikan patokan yang dia pahami sebelumnya dan mengingatkan kembali pada proses melipat ketika dia menggambarkan pola sebelum menggunakan kertas berpetak.

\section{Menemukan Bayangan}

Setelah siswa diminta untuk menempatkan sumbu $x$ dan sumbu $y$ pada posisi lipatan seperti yang dia lakukan ketika menciplak, siswa diminta memilih salah satu kuadran sebagai motif awal. Kemudian menempatkan titik-titik pada kuadran tersebut sesuai dengan kehendak siswa dan menetapkan titik-titik tersebut sebagai titik awal atau titik asal. Sehinga pada tahap ini siswa mengawali dengan pemahaman refleksi dari sebuah titik dan bukan langsung kepada benda secara utuh karena masih adanya penelitian yang menemukan kesalahan-kesalahan yang dilakukan dalam menyelesaikan masalah geometry karena kurangnya pemahaman tentang titik (Maifa, 2019b). Tidak hanya itu, siswa dikenalkan terlebih dahulu dengan refleksi dari titik-titik karena siswa biasanya cenderung menganggap sebuah daerah asal dari refleksi adalah sebuah benda, sehingga kesulitan ketika daerah asalnya berupa titik. (Hollebrands, 2003).

Selanjutnya, Siswa diminta menempatkan 4 titik dan memberi nama titik A,B,C, dan D. Setelah menempatkan titik-titik tersebut, siswa diminta untuk menemukan hasil ciplakan dari 4 titik tersebut ketika diciplak dengan melipat sumbu $x$ dan diciplak dengan melipat sumbu $y$. Pada tahap ini tidaklah sulit untuk siswa, karena siswa sudah mampu menghubungkan informasi-informasi sebelumnya yaitu, kegiatan menciplak, adanya pola awal, pola hasil ciplakan dan batas ciplakan yang sudah mereka tandai sebagai sumbu $x$ dan sumbu $y$. Diperoleh salah satu pekerjaan siswa pada gambar 6 dimana siswa memilih kuadran 1 sebagai motif awal, kemudian hasil ciplakan kepada sumbu $x$ ditandai dengan (A'B'C'D') sedangkan ciplakan kepada sumbu $y$ adalah (A",B',C',D”). 


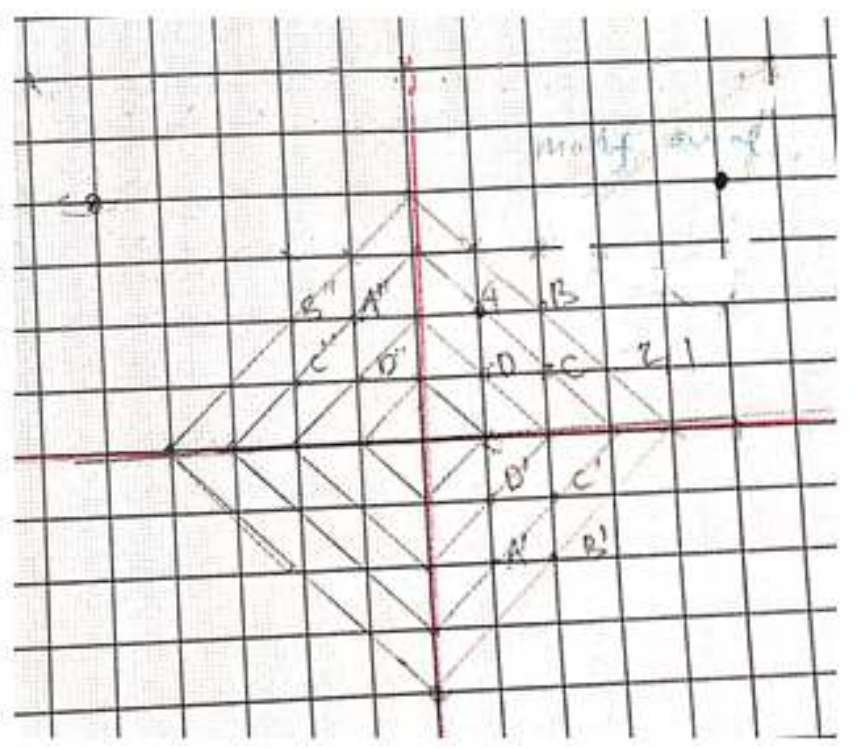

Gambar 6. Hasil ciplakan kepada sumbu $x$ dan sumbu $y$.

Akhir dari kegiatan ini adalah siswa memahami bahwa: (a) Hasil ciplakan merupakan arti dari refleksi; (b) Adanya patokan yang disebut sebagai sumbu refleksi, dalam hal ini adalah sumbu $x$ dan sumbu $y$; (c) Adanya titik-titik pada pola awal dari motif kain Tenun, yang kemudian disebut dengan titik awal; (d) Hasil ciplakan disebut dengan bayangan, yang berupa titik juga; (e) Jarak titik yang dicerminkan kepada sumbu refleksi dan jarak bayangan ke sumbu refleksi adalah sama

4. Menemukan Rumus Refleksi

Setelah aktivitas menemukan bayangan, siswa kemudian mengisi sebuah tabel yang berisi titik-titik awal dan bayangan dari titik awal tersebut. Aktivitas ini dapat dikerjakan siswa dengan mudah.

\begin{tabular}{|c|c|c|}
\hline $\begin{array}{c}\text { Titik Awal } \\
(x, y)\end{array}$ & $\begin{array}{l}\text { Pencerminan/refleksi Tertiadap } \\
\text { Sumbu } x \\
(x ; y)\end{array}$ & $\begin{array}{c}\text { Pencerminanirefleksi Terhadap } \\
\text { Sumbuy } \\
\left(x^{\prime} y^{\prime}\right)\end{array}$ \\
\hline$A(.1 .2 n)$ & $A^{\prime}(.1,=24$ & $A^{\prime \prime}(-1,2)$ \\
\hline$B(2,2$ ) & $B^{\prime}(, 3,-2)$ & $B^{4+}(-2,2)$ \\
\hline$C(2, \ldots 1)$. & $C^{\prime}(2,-1)$ & $C^{\prime \prime}(=2,-1)$. \\
\hline$D(+1-\ldots)$ & $D^{\prime}(\therefore, r-1)$ & $D^{\prime 4}(f, 1, \ldots)$ \\
\hline
\end{tabular}

Gambar 7. Hasil Pekerjaan Siswa mengisi tabel

Aktivitas kemudian diakhiri dengan siswa diminta untuk menemukan pola yang muncul pada tabel yang ditunjukkan pada gambar 7. Siswa diarahkan untuk melihat kaitan antara pasangan berurutan pada titik awal, pada sumbu apa titik tersebut direfleksikan, dan 
Histogram: Jurnal Pendidikan Matematika, 4 (2), 2020 - 448

Talisadika Serrisanti Maifa ${ }^{{ }^{*}}$, Cecilia Novianti Salsinha ${ }^{2}$ Hendrika Bete ${ }^{3}$

bagaimana hasil pasangan berurutan pada bayangannya. Gambar 8 menunjukkan siswa mampu menemukan pola dan pada akhirnya menemukan rumus refleksi terhadap sumbu $x$ dan sumbu $y$.

\begin{tabular}{|c|c|c|}
\hline Titil Assal & $\begin{array}{c}\text { Pencerninanirefleksi } \\
\text { Terhadap Simníxux }\end{array}$ & $\begin{array}{l}\text { Pencerminanirefleksi } \\
\text { Tuthluduap Sumbuy }\end{array}$ \\
\hline$P(x, y)$ & $\left(X_{h}, \ldots Y\right)$ & $(7,2,7)$, \\
\hline
\end{tabular}

Gambar 8. Hasil Pekerjaan Siswa mengisi tabel rumus Refleksi

\section{B. Pembahasan}

Melalui serangkaian aktifitas dalam HLT yang diujicobakan menunjukkan bahwa motif kain Buna dapat digunakan sebagai konteks dalam kegiatan pembelajaran geometri khususnya materi refleksi. Ini tidak jauh berbeda dengan hasil penelitian oleh Deda \& Amsikan (2019) yang juga menyimpulkan bahwa kain tenun Buna mengandung konsep refleksi. Selanjutnya dengan menggunakan pendekatan PMRI pada lintasan belajar ini, dimana pembelajaran didahului dengan sebuah konteks kemudian tahapan berpikir siswa dibangun dengan memanfaatkan eksplorasi dan diskusi antara siswa dan peneliti, siswa aktif dalam mengerjakan Lembar Aktivitas Siswa. Tidak jauh berbeda dengan hasil penelitian Indira dkk, (2018) yang mendapati siswa aktif pada pembelajaran yang menggunakan pendekatan PMRI, pada penelitian ini pun siswa terlibat aktif dalam setiap tahapan dan aktivitas dalam pembelajaran karena adanya diskusi yang membantu terbentuknya tahapan berpikir siswa.

\section{KESIMPULAN DAN SARAN}

\section{A. Kesimpulan}

Lintasan Belajar pada materi Geometri Transformasi khususnya materi Refleksi terdiri dari 4 kegiatan yaitu: menggambarkan pola kain tenun, menciplak pola kain tenun, menemukan bayangan, dan menemukan rumus refleksi. Desain lintasan belajar yang telah dihasilkan mampu mendukung siswa untuk memahami materi Refleksi. Hal ini dapat dilihat dari proses berpikir yang muncul di setiap aktivitas dan aktifnya siswa dalam mengerjakan setiap aktivitas yang diberikan. 
Histogram: Jurnal Pendidikan Matematika, 4 (2), 2020 - 449

Talisadika Serrisanti Maifa ${ }^{*}$, Cecilia Novianti Salsinha ${ }^{2}$ Hendrika Bete $^{3}$

\section{B. Saran}

Desain Lintasan Belajar yang dihasilkan pada penelitian ini dapat dijadikan HLT pada penelitian design research lainnya, khususnya pada pembelajaran Geometri Transformasi

\section{UCAPAN TERIMA KASIH}

Peneliti berterimakasih kepada setiap pihak yang telah memberi sumbangsih kepada peneliti dalam rangka terlaksananya penelitian ini dengan baik dan kepada DRPM yang telah mendanai penelitian ini sebagai penerima dana hibah Penelitian Dosen Pemula tahun pelaksanaan 2020 .

\section{DAFTAR PUSTAKA}

Basuki, N. R. (2012). Analisis Kesulitan Siswa Smk Pada Materi Pokok Geometri Dan Alternatif Pemecahannya. Seminar Nasional Pendidikan Matematika Surakarta 2012, 21(2), 97-104.

Deda, Y. N., \& Amsikan, S. (2019). Geometry Concept on the Motifs of Woven Fabric in Kefamenanu Community. JRAMathEdu (Journal of Research and Advances in Mathematics Education), 1(1), 23-30. https://doi.org/10.23917/jramathedu.v1i1.6253

Eko, Y. S. (2017). The Existence of Ethno mathematics in Buna Woven Fabric and Its Relation to School Mathematics. International Conference on Mathematics and Science Education, May 2017, 128-136.

Gravemeijer, K., \& V. E. (2009). Design Research as a Means for Building a Knowledge Base for Teaching in Mathematics Education. Chicago: The University of Chicago.

Gravemeijer, K., \& Cobb, P. (. (n.d.). Design research from a learning design perspective. In Educational design research.

Guven, B. (2012). Using dynamic geometry software to improve eight grade students' understanding of transformation geometry. Australasian Journal of Educational Technology, 28(2), 364-382. https://doi.org/10.14742/ajet.878

Hollebrands, K. F. (2003). High school student's understanding of geometric transformation in the context of a technological environment. Journal of Mathematical Behavior, 22(1), 55-72. https://doi.org/10.1016/S07323123(03)00004-X

Indira, T., Somakim, S., \& Susanty, E. (2018). Kemampuan Berpikir Kritis Siswa SMP melalui Pendekatan Pendidikan Matematika Realistik Indonesia. HISTOGRAM: Jurnal Pendidikan Matematika, 1(2).

Jumrah, J. (2017). PENINGKATAN PEMAHAMAN KONSEP GEOMETRI MELALUI METODE DEMONSTRASI SISWA KELAS V SDN 186 LEMBANG. HISTOGRAM: Jurnal Pendidikan Matematika, I(2), 12. 
Histogram: Jurnal Pendidikan Matematika, 4 (2), 2020 - 450

Talisadika Serrisanti Maifa ${ }^{1^{*}}$, Cecilia Novianti Salsinha ${ }^{2}$ Hendrika Bete $^{3}$

https://doi.org/10.31100/histogram.v1i1.18

Maifa, T. S. (2019a). Analisis Kesalahan Mahasiswa dalam Pembuktian Transformasi Geometri. Jurnal Riset Pendidikan Dan Inovasi Pembelajaran Matematika (JRPIPM), 3(1), 8. https://doi.org/10.26740/jrpipm.v3n1.p8-14

Maifa, T. S. (2019b). Students 'Understanding of Geometry : Points and Line. November, $138-140$

Ndapa Deda, Y., \& Disnawati, H. (2017). Hubungan Motif Kain Tenun Masyarakat Suku Dawan-Timor Dengan Matematika Sekolah. Knpmp Ii, 18-2017.

Novrika, D., Ilma, R., \& Putri, I. (2016). Menggunakan Motif Kain Batik untuk Siswa Kelas VII. Prosiding Seminar Matematika Dan Pendidikan Matematika, November, $607-626$.

Sudarja, S. E., Aminah, N., \& Hartono, W. (2018). Desain Bahan Ajar Transformasi Geometri Berbasis Kemampuan Komunikasi Matematis Melalui Problem Based Learning. Dialetika Pendidikan Matematika, 5(2), 120-139.

Susanti, D., \& Suparman. (2018). Analisis Kebutuhan Lembar Kerja Siswa Etnomatematika Batik Geometri Transformasi. Prosiding Seminar Nasional Etnomatnesia, 209-213. http://jurnal.ustjogja.ac.id/index.php/etnomatnesia/article/view/2316

Zulkardi, \& Ilma, R. (2006). Mendesain sendiri soal kontekstual matematika. Prosiding KNM13 Semarang, 1-7. 